\title{
PREDICTION OF THREE COMPONENT GAS ADSORPTION WITH IAST AND LANGMUIR
}

\author{
L. H. de OLIVEIRA ${ }^{1}$, J. G. MENEGUIN ${ }^{1}$, E. A. da SILVA ${ }^{2}$, M. A. S. D. de BARROS ${ }^{1}$, P. A. \\ ARROYO $^{1}$, W. M. GRAVA ${ }^{3}$, J. F. do NASCIMENTO ${ }^{3}$ \\ ${ }^{1}$ Universidade Estadual de Maringá - UEM, Departamento de Engenharia Química \\ ${ }^{2}$ Universidade Estadual do Oeste do Paraná - UNIOESTE, Curso de Engenharia Química \\ ${ }^{3}$ Petróleo Brasileiro S.A. - PETROBRAS \\ E-mail para contato: arroyo@ deq.uem.br
}

\begin{abstract}
Purification of natural gas is important to avoid pipe corrosion and improve its specific heat. This operation is mainly focused on hydrogen sulfide and carbon dioxide removal from methane, and adsorption is one of the proposed techniques. In this work, experimental adsorption isotherms for $\mathrm{CH}_{4}, \mathrm{CO}_{2}$ or $\mathrm{H}_{2} \mathrm{~S}$, in $\mathrm{NaY}$ zeolite, at $30^{\circ} \mathrm{C}$ were determined and the Ideal adsorption solution theory (IAST) and Langmuir adsorption isotherm were used to predict the adsorption behavior of the gas mixture composed by $\mathrm{CH}_{4}+\mathrm{CO}_{2}+\mathrm{H}_{2} \mathrm{~S}$, at 1,20 or 50 bar. According to Langmuir equation, the maximum adsorbed capacity was approximately $3.77,7.06$, and $7.02 \mathrm{~mol} / \mathrm{kg}$, for $\mathrm{CH}_{4}$, $\mathrm{CO}_{2}$, and $\mathrm{H}_{2} \mathrm{~S}$, respectively. The calculated values of distribution coefficient $(K)$ and selectivity $(S)$ indicate zeolite adsorbs more $\mathrm{H}_{2} \mathrm{~S}$ than $\mathrm{CO}_{2}$. Also, $K$ values are increased with $\mathrm{CH}_{4}$ content, although $S$ values are greater for high $\mathrm{H}_{2} \mathrm{~S}$ concentration.
\end{abstract}

\section{INTRODUCTION}

In the production of natural gas, purification is necessary to meet pipeline specifications or for commercial use as fuel, and this involves the removal of $\mathrm{H}_{2} \mathrm{~S}$ and $\mathrm{CO}_{2}$, among other components (Koyun et al., 2012; Kunz and Wagner, 2012).

The current technologies for $\mathrm{CO}_{2}$ separation from gas streams in mainly composed by solvents, membranes and sorbents (Li et al., 2013). The sorbent technology includes materials such as zeolite (Maurin et al., 2007), activated carbon (Schell et al., 2012), silica (Watabe and Yogo, 2013), and metal organic frameworks (Chaemchuen et al., 2013).

Removal of $\mathrm{H}_{2} \mathrm{~S}$ from gas mixtures, such as natural gas, belongs to a broader and important area, namely, the desulfurization of hydrocarbons. Remove sulfur from hydrocarbon streams can be carried out by: a) extraction with amine solution, b) catalytic hydrodesulfurization at elevated temperatures and pressures, c) catalytic oxidation/adsorption with metal oxides, and d) adsorption on solid adsorbents at mild conditions of temperature and pressure (Kumar et al., 2011; Ratsanamy et al., 2012). Considering adsorption, the majority of the studies are about $\mathrm{H}_{2} \mathrm{~S}$ adsorbed on activated carbon, as an example, the work of Bandosz (1999), but also there are some works using zeolites, 
such as those reported by Cruz et al. (2005), Melo et al. (2006), Crespo et al. (2008), Alonso-Vicario et al. (2010), and Kumar et al. (2011)

The sorbent technology is used in different ways, depending on the degree of purification desired. In this way, swing adsorption processes can be used with operation variables such as pressure (PSA), temperature (TSA), pressure and temperature (PTSA), concentration (CSA) and electric systems (ESA) can take place.

Design and optimization of industrial operations like PSA can be realized after the knowledge of equilibrium in adsorption process. It is also necessary for the evaluation of adsorption capacity and adsorbents selectivity. Besides, multicomponent adsorption experiments are too laborious, and it is desirable to employ approaches that allow the prediction of such systems from experimental data (Rios et al., 2013)

In this work, isotherms for $\mathrm{CH}_{4}, \mathrm{CO}_{2}$ or $\mathrm{H}_{2} \mathrm{~S}$ adsorbed in $\mathrm{NaY}$ zeolite were measured experimentally. One-component data were modelled with conventional equations that provided a prediction for adsorption behavior of the ternary mixture.

\section{EXPERIMENTAL}

Pure component isotherms were measured in a Rubotherm Magnetic Suspension Balance (Bochum, Germany) without an in-situ density measurement. The gas density was estimated with Peng-Robinson equation of state (Peng and Robinson, 1976). The measurements were made as pointed out by Dreisbach et al. (2002) and Keller and Staudt (2005). The pressure range used was: 0.4 to 45 bar, for $\mathrm{CH}_{4} ; 0.4$ to 40 bar, for $\mathrm{CO}_{2} ; 0.02$ to 1.8 bar, for $\mathrm{H}_{2} \mathrm{~S}$. Temperature was kept constant at $30^{\circ} \mathrm{C}$ with a water circulating bath.

\section{MODELLING}

Modelling used in this work is similar to that reported by Schell et al. (2012), but here the ternary behavior was predicted instead of the binary.

The one-component data was correlated with Langmuir isotherm, shown by Equation 1:

$$
q=q_{\max } \frac{b P}{1+b P}
$$

In Equation 1, $\mathrm{P}$ is the pressure (bar), $q$ is the adsorbed amount (mol/kg), $q_{\max }$ is the maximum adsorbed amount $(\mathrm{mol} / \mathrm{kg})$, and $\mathrm{b}$ is the energetic parameter $(1 / \mathrm{bar})$.

With the Langmuir isotherm parameters fitted to the experimental results of the pure components, ternary equilibria were predicted using ideal adsorbed solution theory, or IAST (Myers and Prausnitz, 1965). 


\subsection{Calculation procedure}

Initially, the pressure $(P)$ and mole fraction $(y)$ of the gas phase in equilibrium with an adsorbed phase is chosen. Considering that gas phase can be described by Raoult's law, the partial pressure of each $i$ component is calculated as $P \cdot y_{i}$.

For the ideal adsorption solution, at constant temperature, Equation 2 gives the equilibrium criterion:

$$
P y_{i}=P_{i}^{o} x_{i}
$$

where $P_{i}^{o}$ is the pure adsorbate vapor pressure for component $i$ at the temperature and spreading pressure $(\pi)$ of the solution, and $x_{\mathrm{i}}$ is the mole fraction of component $i$ in adsorbed phase. $P_{i}^{o}$ is obtained by Equation 3:

$$
Z=\int_{P=0}^{P=P_{i}^{o}} q d \ln P
$$

where $Z$ is the compressibility factor. For adsorbed phase, $Z$ is determined according to Equation 4 :

$$
Z=\frac{P V}{R T}=\frac{\pi A}{R T}
$$

where $R$ is the ideal gas constant (J/mol.K), $T$ is the absolute temperature $(\mathrm{K}), A$ is the area occupied by adsorbed phase $\left(\mathrm{m}^{2}\right)$, and $\pi$ is the spreading pressure (bar.m). Inserting Equation 1 into 3 and solving the integral, Equation 5 is obtained:

$$
P_{i}^{o}=\frac{\exp \left(\frac{Z}{q_{m, i}}\right)-1}{b_{i}}
$$

where $q_{m, i}$ and $b_{i}$ are the Langmuir parameters for component $i$.

With Equations 2 and 5, the values of $x_{i}$ can be estimated guessing values for $Z$ and minimizing the objective function $(F)$ shown by Equation 6: 


$$
F=\sum_{i}\left(x_{i}\right)-1
$$

As a result, partition coefficients for each component $(K)$ and the selectivity $(S)$, given by Equations 7 and 8, can be calculated:

$$
\begin{gathered}
K_{i}=\frac{x_{i}}{y_{i}} \\
S_{i}=\frac{K_{i}}{K_{j}}
\end{gathered}
$$

In Equation 8, $i=\mathrm{CO}_{2}$ or $\mathrm{H}_{2} \mathrm{~S}$, and $j=\mathrm{CH}_{4}$.

The conditions used for modelling were: pressure equal to 1, 20, and $50 \mathrm{bar}$; and temperature equal to $30^{\circ} \mathrm{C}$. The calculation procedure was performed with Microsoft Excel® Solver; and Evolutionary method was employed without change the initial set of variables.

\section{RESULTS AND DISCUSSION}

\subsection{Adsorption isotherms}

The adsorption isotherms obtained for $\mathrm{CH}_{4}, \mathrm{CO}_{2}$ or $\mathrm{H}_{2} \mathrm{~S}$ are shown in Figure 1. It can be verified that $\mathrm{H}_{2} \mathrm{~S}$ presents a greater affinity for $\mathrm{NaY}$ zeolite than $\mathrm{CO}_{2}$ or $\mathrm{CH}_{4}$. This is due to its strong interaction with zeolite behavior, characterized by three different adsorption behavior (Maugé et al., 2002).

Langmuir curves fitted to each experimental adsorption isotherm are also shown in Figure 1, and the estimated parameters are in Table 1 . The $b$ values shown indicate quantitatively that adsorption interaction with $\mathrm{NaY}$ zeolite presents the order $\mathrm{H}_{2} \mathrm{~S}>\mathrm{CO}_{2}>\mathrm{CH}_{4}$.

\subsection{Partition coefficients and selectivities}

The modelling results are grouped in Figure 2. They covered all range of compositions for the ternary mixture, and so equilateral triangles were employed. The pressures chosen to input the modelling were 1, 20 and 50 bar, but only the results at 1 bar are shown, since the results for the other two pressures were very similar.

From calculated data depicted in Figures $2 \mathrm{a}$ and $2 \mathrm{~b}$, it is verified that Langmuir joined with IAST indicate higher partition coefficients for both low $\mathrm{H}_{2} \mathrm{~S}$ and $\mathrm{CO}_{2}$ concentration. The partition coefficient for $\mathrm{H}_{2} \mathrm{~S}$ is higher than for $\mathrm{CO}_{2}$, and it is related with the $b$ value for each gas shown in 
Table 1.

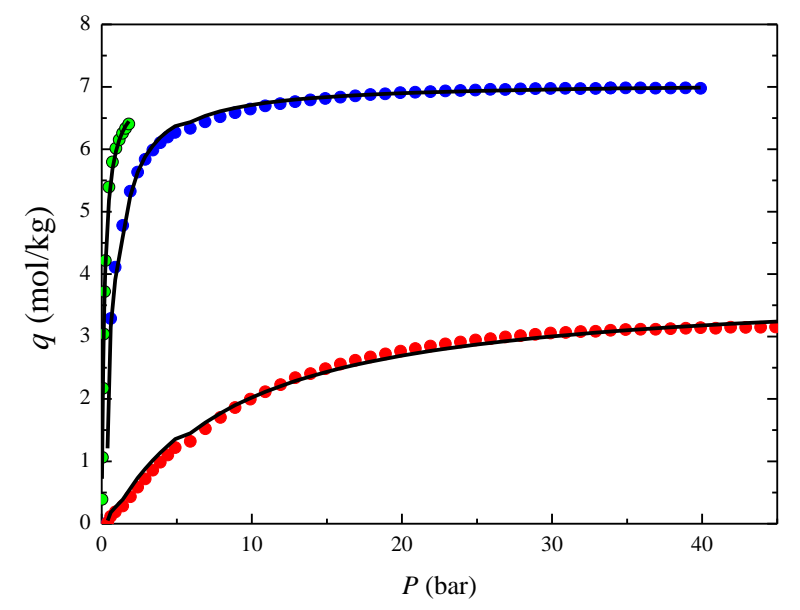

Figure 1 - Adsorption isotherms obtained for $\mathrm{CH}_{4}$ (red), $\mathrm{CO}_{2}$ (blue) and $\mathrm{H}_{2} \mathrm{~S}$ (green), in $\mathrm{NaY}$ zeolite, at $30^{\circ} \mathrm{C}$.

Table 1 - Langmuir estimated parameters

\begin{tabular}{|c|c|c|}
\hline Gas & $q_{\max }(\mathrm{mol} / \mathrm{kg})$ & $b\left(\mathrm{bar}^{-1}\right)$ \\
\hline $\mathrm{CH}_{4}$ & 3.7762 & 0.0032 \\
\hline $\mathrm{CO}_{2}$ & 7.0553 & 2.0586 \\
\hline $\mathrm{H}_{2} \mathrm{~S}$ & 7.0183 & 5.6354 \\
\hline
\end{tabular}

Selectivities values shown in Figures $2 \mathrm{c}$ and 2d, indicate that zeolite have great affinity for $\mathrm{H}_{2} \mathrm{~S}$ and $\mathrm{CO}_{2}$, and that $S_{\mathrm{H} 2 \mathrm{~S}}$ is greater than two times $S_{\mathrm{CO} 2}$. Also, a different trend is presented for selectivity. As the concentration of $\mathrm{CH}_{4}$ is increased, the $S$ values for both gases decrease.

These results are interesting, since they provide that the possible use for zeolites on the natural gas purification should be downstream a bulk purification, generally carried out with with amines, membranes or oxides, as stated in Introduction section.

However, zeolite $\mathrm{NaY}$ seem to be technically promising for $\mathrm{CH}_{4}$ separation due to high $S$ values achieved. A more robust modelling allied to experiments with binary and ternary mixtures, in equilibrium and dynamic forms, should give a definitive answer for this process. 


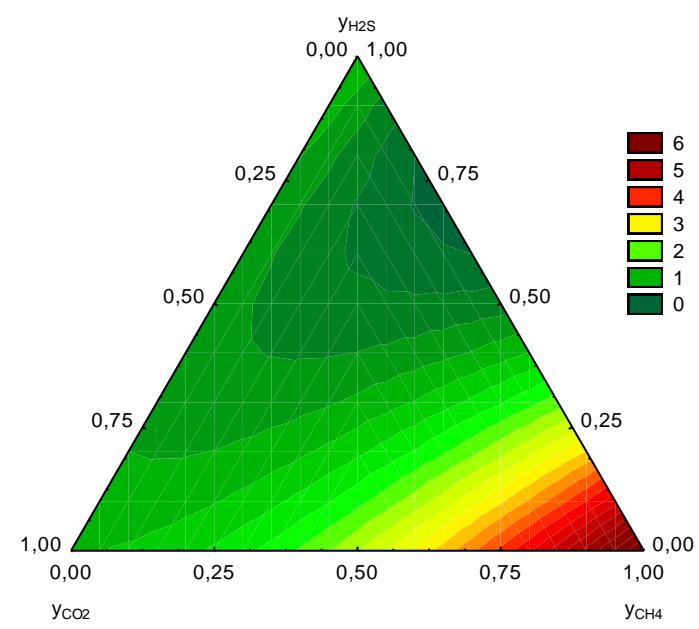

(a) $K_{\mathrm{CO} 2}$

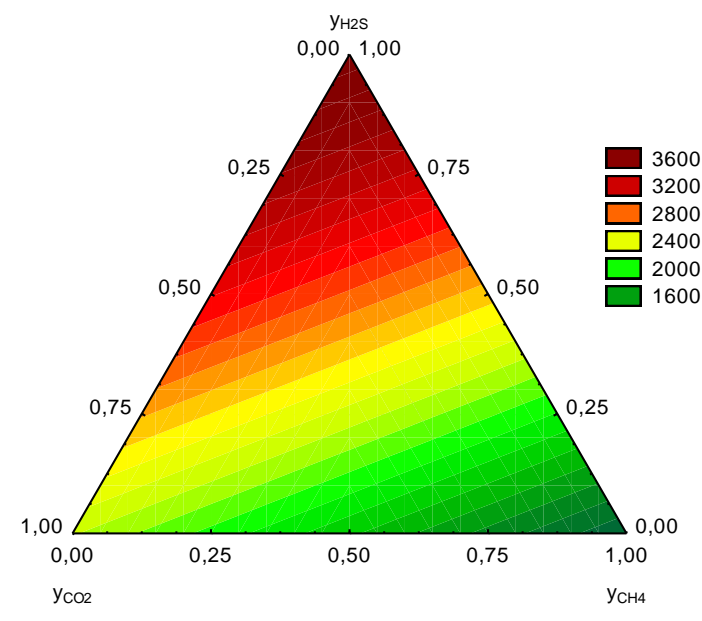

(c) $S_{\mathrm{CO} 2}$

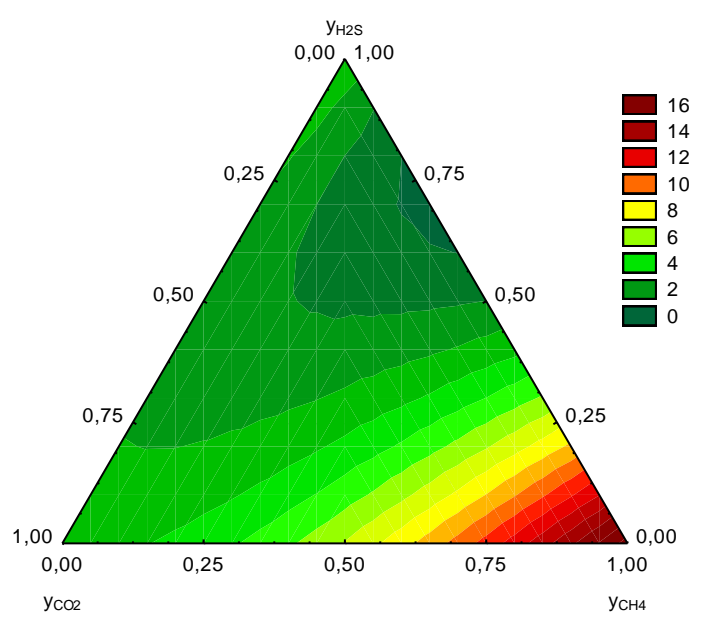

(b) $K_{\mathrm{H} 2 \mathrm{~S}}$

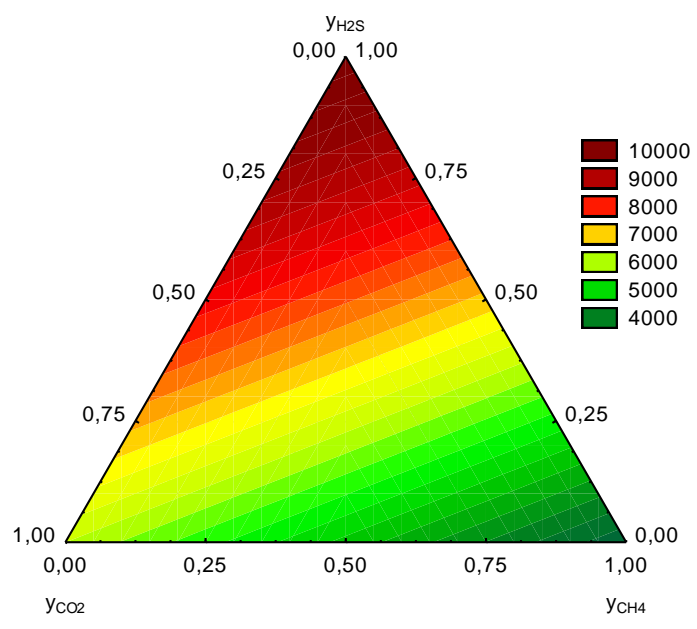

(d) $S_{\mathrm{H} 2 \mathrm{~S}}$

Figure 2 - Partition coefficients and selectivities for $\mathrm{CO}_{2}$ and $\mathrm{H}_{2} \mathrm{~S}$ at $30^{\circ} \mathrm{C}$ and 1 bar.

\section{CONCLUSIONS}

Ideal adsorption solution theory (IAST) and Langmuir adsorption isotherm were used to predict the adsorption behavior of the gas mixture $\mathrm{CH}_{4}+\mathrm{CO}_{2}+\mathrm{H}_{2} \mathrm{~S}$ in $\mathrm{NaY}$ zeolite, at $30^{\circ} \mathrm{C}$ and 1,20 or 50 bar. Langmuir equation gives a maximum adsorbed capacity of 3.77, 7.06, and $7.02 \mathrm{~mol} / \mathrm{kg}$, for $\mathrm{CH}_{4}$, $\mathrm{CO}_{2}$, and $\mathrm{H}_{2} \mathrm{~S}$, respectively. Distribution coefficient $(K)$ and selectivity $(S)$ indicate zeolite adsorbs more $\mathrm{H}_{2} \mathrm{~S}$ than the other gases. Also, $K$ values are increased with $\mathrm{CH}_{4}$ content, although $S$ values are greater for high $\mathrm{H}_{2} \mathrm{~S}$ concentration. These results accord with the sequence of affinity presented by $b$ parameter of Langmuir equation. Hence, $\mathrm{NaY}$ zeolite seem to be technically promising for $\mathrm{CH}_{4}$ separation due to high $S$ values achieved. 


\section{ACKNOWLEDGEMENTS}

The authors would like to thank Petrobras for the financial support (project number 0050.0073910.12.9).

\section{REFERENCES}

ALONSO-VICARIO, A.; OCHO-GÓMEZ, J. R.; GIL-RÍO, S.; GÓMEZ-JIMÉNEZ-ABERASTURI, O.; RAMÍREZ-LÓPEZ, C. A.; TORRECILLA-SORIA, J.; DOMÍNGUEZ, A. Purification and upgrading of biogas by pressure swing adsorption on synthetic and natural zeolites. Micropor. Mesopor. Mat., v. 134, p. 100-107, 2010.

BANDOSZ, T. J. Effect of pore structure and surface chemistry of virgin activated carbons on removal of hydrogen sulfide. Carbon, v. 37, p. 483-491, 1999.

CHAEMCHUEN, S.; KABIR, N. A.; ZHOU, K.; VERPOORT, F. Metal-organic frameworks for upgrading biogas via $\mathrm{CO}_{2}$ adsorption to biogas green energy. Chem. Soc. Rev., v. 42, p. 93049332, 2013.

CRESPO, D.; QI, G.; WANG, Y.; YANG, F. H.; YANG, R. T. Superior Sorbent for Natural Gas Desulfurization. Ind. Eng. Chem. Res., v. 47, p. 1238-1244, 2008.

CRUZ, A. J.; PIRES, J.; CARVALHO, A. P.; de CARVAlHO, M. B. Physical Adsorption of H2S Related to the Conservation of Works of Art: The Role of the Pore Structure at Low Relative Pressure. Adsorption, v. 11, p. 569-576, 2005.

DREISBACH, F., LÖSCH, H. W., HARTING, P. Highest Pressure Adsorption Equilibria Data: Measurement with Magnetic Suspension Balance and Analysis with a New Adsorbent/Adsorbate-Volume. Adsorption, v. 8, p. 95-109, 2002.

KELLER, J., STAUDT, R. Gas Adsorption Equilibria, Springer Science, 2005.

KOYUN, T.; KUNDUZ, M.; OZTOP, H. F.; UCGUL, I. Comparison of purification processes of natural gas obtained from different regions in the world. J. Nat. Gas Chem., v. 21, p. 61-68, 2012.

KUMAR, P.; SUNG, C.-Y.; MURAZA, O.; COCOCCIONI, M.; HASHIMI, S. A.; MCCORMICK, A.; TSAPATSIS, M. $\mathrm{H}_{2} \mathrm{~S}$ adsorption by $\mathrm{Ag}$ and $\mathrm{Cu}$ ion exchanged faujasites. Micropor. Mesopor. Mat., v. 146, p. 127-133, 2011.

KUNZ, O; WAGNER, W. The GERG-2008 Wide-Range Equation of State for Natural Gases and Other Mixtures: An Expansion of GERG-2004. J. Chem. Eng. Data, v. 57, p. 3032-3091, 2012

LI, B.; DUAN, Y.; LUEBKE, D.; MORREALE, B. Advances in CO2 capture technology: A patent review. Applied Energy, v. 102, p. 1439-1447, 2013.

MAUGÉ, F.; SAHIBED-DINE, A.; GAILlARD, M.; ZIOLEK, M. Modification of the Acidic Properties of $\mathrm{NaY}$ Zeolite by $\mathrm{H}_{2} \mathrm{~S}$ Adsorption - An Infrared Study. J. Catal., v. 207, p. 353-360, 2002. 
MAURIN, G.; BELMABKHOUT, Y.; PIRNGRUBER, G.; GABEROVA, L.; LLEWELLYN, P. CO 2 adsorption in $\mathrm{LiY}$ and $\mathrm{NaY}$ at high temperature: molecular simulations compared to experiments. Adsorption, v. 13, p. 453-460, 2007.

MELO, D. M. A.; de SOUZA. J.R.; MELO, M. A. F.; MARTINELLI, A. E.; CACHIMA, G. H. B.; CUNHA, J. D. Evaluation of the zinox and zeolite materials as adsorbents to remove $\mathrm{H}_{2} \mathrm{~S}$ from natural gas. Colloid. Surface A, v. 272, p. 32-36, 2006.

MYERS, A. L.; PRAUSNITZ, J. M. Thermodynamics of mixed gas adsorption. AIChE J., v. 11, p. 121-127.

PENG, D. Y.; ROBINSON, D. B. A new two-constant equation of state. Ind. Eng. Chem. Fund., v. 15, p. 59-64, 1976.

RATSANAMY, C.; WAGNER, J. P.; SPIVEY, S.; WESTON, E. Removal of sulfur compounds from natural gas for fuel cell applications using a sequential bed system. Catal. Today, v. 198, p. 233238, 2012.

RIOS, R. B.; STRAGLIOTTO, F. M.; PEIXOTO, H. R.; TORRES, A. E. B.; BASTOS-NETO, M.; AZEVEDO, D. .C. S.; CAVALCANTE JR., C. L. Studies on the adsorption behavior of $\mathrm{CO}_{2-}$ $\mathrm{CH}_{4}$ mixtures using activated carbon. Braz. J. Chem. Eng., v. 30, p. 939-951, 2013.

SCHELL, J.; CASAS, N.; PINI, R.; MAZZOTTI, M. Pure and binary adsorption of $\mathrm{CO}_{2}, \mathrm{H}_{2}$, and $\mathrm{N}_{2}$ on activated carbon. Adsorption, v. 18, p. 49-65, 2012.

WATABE, T.; YOGO, K. Isotherms and isosteric heats of adsorption for $\mathrm{CO}_{2}$ in aminefunctionalized mesoporous silicas. Sep. Purif. Technol., v. 120, p. 20-23, 2013. 